\title{
Impact of antibiotic-impregnated catheters on the reduction in operations for cerebrospinal fluid shunt infection since 1995: evidence from the UK Shunt Registry
}

\author{
John D Pickard", Hugh K Richards, Helen M Seeley
}

From Hydrocephalus 2015

Banff, Canada. 18-21 September 2015

\section{Introduction}

Various methods have been introduced to reduce CSF shunt infection including institutional protocols, antibiotic prophylaxis and antibiotic-impregnated catheters. Have such measures led to a sustainable reduction in CSF shunt infections?

\section{Methods}

The United Kingdom Shunt Registry is a paper-based reporting system for CSF shunts inserted in the 34 UK neurosurgery units since May 1995. This Report is based on data downloaded on 23rd January 2015 from the master database that gave a shunt procedure dataset from 1st January 1995 to 31st December 2014 of 53,767 procedures in 29,341 patients. The infection risk was calculated as the proportion of procedures subsequently revised for infection based on "intention to treat" recorded at the time of surgery where the follow-up was greater than nine months. Subsequent bacteriological confirmation was not available.

\section{Results}

There was a trend towards a fall in shunt infection risk in both adults and children over recent years. With regard to the impact of the introduction of antibiotic-impregnated catheters, our previously published study was based on a cohort of 994 pairs matched for age, diagnosis, number of previous procedures and gender procedures recruited up until the end of 2006. The infection risk in that cohort was reduced from $4.7 \%$ using conventional catheters to $3.0 \%$ using Bactiseal catheters. Data from 2007 onwards was used to construct a second matched-pair comparison. 11938 procedures were identified where patients could be defined by age, diagnosis gender and number of previous revisions. 6302 antibiotic-impregnated catheters and 5636 conventional catheters were used. This data set yielded 4011 matched pairs. The calculated infection risk was $1.87 \%$ in conventional catheters and $1.12 \%$ in antibioticimpregnated catheters $(\mathrm{p}=0.006)$.

\section{Conclusions}

The overall risk of shunt infection at all ages has reduced over recent years. Antibiotic-impregnated catheters have significantly reduced shunt infections but other factors may have played a role.

Published: 18 September 2015

\section{References}

1. Richards HK, Seeley HM, Pickard JD: Efficacy of antibiotic-impregnatd catheters in reducing shunt infection: data from the UK shunt registry. J Neurosurg Pediatr 2009, 4:389-93.

2. Santarius T, Kirkpatrick PJ, et al: Use of drains versus no drains after burr-hole evacuation of chronic subdural haematoma: a randomised controlled trial. Lancet 2009, 374:1067-73.

3. Keong NC, Bulters DO, et al: The SILVER (silver impregnated line versus EVD randomised trial): a double-blind, prospective, randomised trial of an intervention to reduce the rate of external ventricular drain infection. Neurosurgery 2012, 71:394-403.

4. Higgins JN, Pickard JD: Intractable headache after excision of an acoustic neuroma treated by stent revascularisation of the sigmoid sinus. Br J Neurosurg 2013.

5. Chennu S, Finoia P, Kamau E, Monti MM, Allanson J, Pickard JD, Owen AM, Bekinschtein TA: Dissociable endogenous and exogenous attention in disorders of consciousness. Neuroimage Clin 2013 Oct 16, 3:450-61.

* Correspondence: jdp1000@cam.ac.uk 
6. Chari A, Czosnyka M, Richards HK, Pickard JD, Czosnyka ZH: Hydrocephalus shunt technology: 20 years of experience from the Cambridge Shunt Evaluation Laboratory. J Neurosurg 2014, Jan 3. [Epub ahead of print].

7. Higgins N, Pickard J, Lever A: Lumbar puncture, chronic fatigue syndrome and idiopathic intracranial hypertension: a cross-sectional study. JRSM Short Rep 2013, 4(12), 2042533313507920. doi: 10.1177/2042533313507920. eCollection 2013 Dec.

8. Capel C, Kasprowicz M, Czosnyka M, Baledent O, Smielewski P, Pickard JD, Czosnyka Z: Cerebrovascular time constant in patients suffering from hydrocephalus. Neurol Res 2014, 36(3):255-61.

doi:10.1186/2045-8118-12-S1-09

Cite this article as: Pickard et al:: Impact of antibiotic-impregnated catheters on the reduction in operations for cerebrospinal fluid shunt infection since 1995: evidence from the UK Shunt Registry. Fluids and Barriers of the CNS 2015 12(Suppl 1):09.

\section{Submit your next manuscript to BioMed Central} and take full advantage of:

- Convenient online submission

- Thorough peer review

- No space constraints or color figure charges

- Immediate publication on acceptance

- Inclusion in PubMed, CAS, Scopus and Google Scholar

- Research which is freely available for redistribution

Submit your manuscript at www.biomedcentral.com/submit 